\title{
Doença do refluxo gastroesofágico e retardo de linguagem: estudo de caso clínico $* * * *$
}

\author{
Gastroesophageal reflux disease and delay in language acquisition \\ delay: clinical case study
}

\author{
Fernanda Prada Machado* \\ Maria Claudia Cunha** \\ Ruth Ramalho Ruivo Palladino***
}

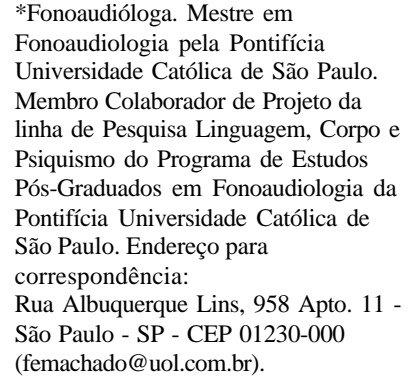

**Fonoaudióloga. Professora Titular do Departamento de Clínica

Fonoaudiológica da Faculdade de

Fonoaudiologia da Pontifícia

Universidade Católica de São Paulo.

***Fonoaudióloga. Doutora em Psicologia Clínica. Professora Assistente do Departamento de Clínica Fonoaudiológica da Faculdade de Fonoaudiologia da Pontifícia Universidade Católica de São Paulo.

****Trabalho Realizado no Programa de Estudos Pós-Graduados em

Fonoaudiologia da Pontifícia

Universidade Católica de São Paulo.

\begin{abstract}
Background: co-occurrence of feeding and language disorders. Aim: to investigate possible connections between feeding and language disorders, based on a bio-psychic perspective. Method: a clinical-qualitative methodology, developed through a longitudinal study of a clinical case of a three year old boy with the complaint "does not speak or eat" and with a medical diagnosis of gastroesophageal reflux disease. Results: the analyzed case was considered emblematic of connections between feeding and language disorders. Conclusions: results indicate that there is a relationship between oral language and feeding problems. It is suggested for speech-language therapists who work with language problems to investigate feeding habits, as well as for those who for with the stomatognathic system to investigate the oral language of their patients.
\end{abstract}

Key Words: Language Disorders; Language; Feeding Behavior.

\section{Resumo}

Tema: co-ocorrência entre problemas alimentares e de linguagem oral. Objetivo: investigar as possíveis relações entre problemas de alimentação e de linguagem oral, do ponto de vista bio-psíquico. Método: clínico-qualitativo, desenvolvido por meio de estudo longitudinal de um caso clínico, de um menino de três anos, com a queixa "não fala e não come" e com diagnóstico de doença do refluxo gastroesofágico. Resultados: o caso analisado configurou-se como emblemático da presença de relações entre problemas de linguagem oral e de alimentação. Conclusão: os resultados indicam que há relação entre os problemas de alimentação e de linguagem oral. Sendo assim, sugere-se que os fonoaudiólogos que se ocupam dos problemas de linguagem em crianças, investiguem as condutas alimentares. Da mesma forma, sugere-se que o fonoaudiólogo que trabalha com o sistema estomatognático, investigue a linguagem oral de seus pacientes.

Palavras-Chave: Transtornos da Linguagem; Linguagem; Comportamento Alimentar.

Artigo Relato de Caso

Artigo Submetido a Avaliação por Pares

Conflito de Interesse: não

Recebido em 22.11.2007.

Revisado em 13.05.2008; 16.08.2008;

2.12.2008.

Aceito para Publicação em 03.02.2009.

Referenciar este material como:

- _- Machado FP, Cunha MC, Palladino RRR. Gastroesophageal reflux disease and delay in language acquisition delay: clinical case study (original title: Doença do Z 3 refluxo gastroesofágico e retardo de linguagem: estudo de caso clínico). Pró-Fono Revista de Atualização Científica. 2009 jan-mar;21(1):81-3. 


\section{Introduction}

Co-occurrence of feeding and language disorders studies outline subjective aspects (about what is particular of each clinical case history) implied, configuring what is called problems in the orality, that is, in the mouth's erogenous maturation process 1-4.

Aim

To examine possible connections between feeding and language disorders, from the biopsychic perspective.

\section{Method}

This research was approved by the Ethical Committee of the Institution in which it was developed (process number 0035/20).

Clinical-qualitative research, by means of a case study of Rafael, of a three year old boy with a complaint that: "he neither spoke nor ate". Data were gathered in a twelve month therapeutic process period; written register of clinical material based on language, feeding and psychics, was made. The analysis was subsidized by the literature in speech therapy about the oral language acquisition, oral facial motor system and psychoanalysis related to feeding disorders, considered as problems in the oral function.

\section{Results}

Rafael begins speech therapy between 3 and 6 years old. The boy was born with $3.5 \mathrm{~kg}$, after 42 weeks of pregnancy. He had jaundice and remained at a Neonatal Intensive Care Unit (NICU) for 3 days; he was fed after the second day of life, since his other has no milk before that. He was weaned by six months of age, because his mother had to get back to work and when he was already eating soft food. He began to present a first symptom: vomit everything he ate. When he is 2:6 years old he receives a medical diagnosis of gastro-esophageal reflux disease, and at 4 years old, he has an autistic spectrum disorder diagnosis. In the beginning of the speech therapy he avoids contact with the therapist, has no interest in play activities, does not speak, although expresses himself throughout gestures. He refuses any type of solid food and accepts only liquid and soft food. He chokes and presents vomit reflex. It is important to outline as a rare and emblematic data that the solid food refusal presented by the patient cannot be justified by his clinical case of gastro-esophageal reflux disease, as long as patients with such disease use to avoid liquid and pasty food, once they cause great discomfort 5-6. What happens with Rafael was exactly the opposite; he would rather have liquid and pasty food than solid, which reinforces the interference of psychic factors in the symptom's constitution. The therapeutic process has been developed throughout food scenes, dialogic and play activities aiming at improving:

1. Discursive exchange between therapist and patient.

2. Patient's feeding conducts, with specific techniques to oral region desensitization and vomit reflex postponement.

As a result of this procedure, we observed that:

1. The feeding scenes gradually became more pleasant for the patient; choke and vomit reflex became less frequent and effective introduction of solid food has begun.

2. The child has started babbling, produced his first words and assumed an interlocution conduct related to the other.

\section{Discussion}

In Rafael's case, co-occurrence of symptoms presented plus life history and psychic functioning have provided a therapeutic intervention at the biopsychic dimensions, either related to the oral language problems, confirming literature data 1,3 . The feeding scene as a therapeutic tool has been effective.

\section{Conclusion}

In this clinical case, results indicate there seems to be a relationship between feeding and oral language problems, from the bio-psychical point of view. Therefore, we suggest that an investigation of the feeding conducts, even though there is no related complaint, be part of the routine of the speech therapists who work with language disorders in children. Likewise, we also suggest the professional who works with the stomatognathic system to investigate oral language functioning of his patients. 


\section{Referências Bibliográficas}

1. Palladino RRR, Cunha MC, Souza LAP. Language and eating problems in children: co-occurrences or coincidences?. Pró-Fono Revista Atualização Científica. 2007 abr-jun;19(2):205-14.

2. Thibault C. La langue, organe clé des oralités. Rééducationa Orthophonique. 2006;44(226):115-24.

3. Greer AJ, Gulotta CS, Masler EA, and Laud RB. Caregiver Stress and Outcomes of Children with Pediatric Feeding Disorders Treated in an Intensive Interdisciplinary Program. Journal of Pediatric Psychology. 2008;33(6):61220 .
4. McDermott BM, Mamun AA, Najman JM, Williams GM, O'Callaghan MJ, Bor W. Preschool children perceived by mothers as irregular eaters: Physical and psychosocial predictors from a birth cohort study. Journal of Developmental and Behavioral Pediatrics. 2008;29(3):197205.

5. Drent LV, Pinto EALC. Feeding disorders in children with gastro-esophageal reflux disease. Pró-Fono Revista Atualização Científica. 2007;19(1):59-66.

6. Armstrong D. Gastroesophageal reflux disease - a chronic, persistent disease: A systematic review of the literature. Gastroenterology. 2008;134(4):A175-A176. 